Bull. Environ. Contam. Toxicol. 30, 309-316 (1983)

(C) 1983 Springer-Verlag New York Inc.

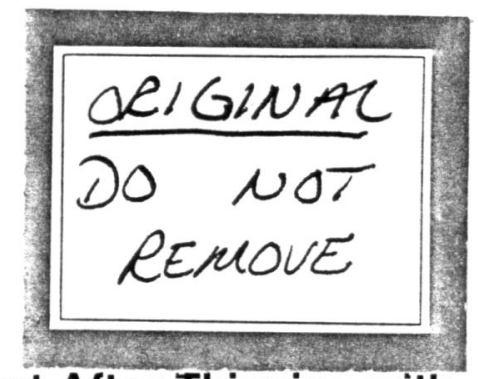

\title{
Arsenic in the Forest Environment After Thinning with MSMA and Cacodylic Acid
}

\author{
Logan A. Norris, ${ }^{1}$ Paul R. Canutt, ${ }^{2}$ and John F. Neuman ${ }^{3}$ \\ ${ }^{1}$ Forest Science Laboratory, Pacific Northwest Forest and Range Experiment \\ Station, Corvallis, OR; ${ }^{2}$ Region 6, USDA Forest Service, Portland, OR; \\ ${ }^{3}$ Washington State Dept. of Social and Health Services, Wenatchee, WA
}

The organic arsenic-containing herbicides, cacodylic acid (hydroxydimethylarsine oxide acid) and MSMAT (monosodium methanearsonate), are used for precommercial thinning by stem injection in Pacific Northwest forests. Data are available on the distribution and persistence of MSMA and cacodylic acid in agricultural environments, but little attention has been given to the forest. Our study determined (1) the concentration of arsenic in forest floor, soil, and herbaceous and browse vegetation after injecting individual trees with MSMA and (2) the concentration of arsenic in streams flowing through forests operationally thinned with the arstricals.

\section{MATERIALS AND METHODS}

This study was conducted on three types of forest Douglas-fir, ponderosa pine, and western larch in the Okanogan Highlands, northeastern Washington (FRANKLIN and DYRNESS 1973). Ponderosa pine typically are at the lowest elevations and on the warmest, driest sites, Douglas-fir are intermediate, and the western larch are at higher elevations and on cooler, moister sites. In each forest, $1 \mathrm{ml}$ of undiluted MSMA formulation was squirted into axe cuts spaced about $7.5 \mathrm{~cm}$ apart around the bole of each of five trees. Three transects were projected from each tree with sampling points at $0.5,2.0$, and 4.0 times the crown radius from the bole. Samples of the same type collected at a given distance were composited and analyzed for total arsenic. Sample materials collected were: forest floor (L, F, and $H$ horizons), mineral soil (0- to $30-\mathrm{cm}$ depth), browse vegetation (terminal $10-\mathrm{cm}$ branch tips), and herbaceous vegetation (above ground portions). Each forest type (with 5 trees as replicates) constituted a separate randomized block, split plot experiment with distance as the whole plot and time and the time-distance interaction as the split plot.

Water monitoring for arsenic was conducted during and after operational precommercial thinning on three National Forests. Stream sampling stations were located both up and downstream

1 This publication reports research involving pesticides. It does not contain recommendations for their use nor does it imply that the uses discussed here have been registered. All uses of pesticides must be registered by appropriate State and/or Federal agencies before they can be recommended. 
from areas ( 50 to $150 \mathrm{ha}$ ) treated with MSMA ( 3 areas) or cacodylic acid (1 area). Samples were collected during application, storms, and spring runoff (up to 9 months after application).

All samples were analyzed for total arsenic content. Nitric-sulfuric acid digestion converted arsenic to arsenious oxide which was reduced to arsine, complexed with diethyldithiocarbamate and measured at $535 \mathrm{~nm}$ (ASSOCIATION OFF ICIAL ANALYTICAL CHEMISTS 1970).

Data for each sample type in each forest were analyzed separately by analysis of variance. Orthogonal polynomial contrasts tested for relationships between level of arsenic and both distance from treated stems and time after application. Where the analysis of variance showed a significant effect of time, a one-tailed T-test was used to test for differences between pretreatment and individual post treatment arsenic levels.

\section{RESULTS}

Ponderosa Pine Forest

There was no statistically significant change in arsenic concentrations with time after treatment in either herbs of browse, al though the mean values suggest a logical trend (Table 1). The arsenic concentration in herbs decreased linearly with distance from treated trees, but the apparent similar decrease in browse was not statistically significant. In the forest floor, the concentration of arsenic increased substantially the first summer after application, particularly directly under the canopy. Except at the 0.5 crown radius location, arsenic concentrations in the forest floor were not significantly different from pretreatment values by the second summer after application. This area had been machine scarified some time before thinning, and little forest floor material was present at time of treatment. The large increase in arsenic concentration in the forest floor reflects this lack of "old litter" to dilute freshfall litter from treated trees. The large input of arsenic to the forest floor had little effect on soil arsenic levels. The level of arsenic in soil did not change significantly with either time or distance.

\section{Douglas-Fir Forest}

The arsenic concentration in herbs and browse increased after treatment but differences between pretreatment and specific post treatment dates were significantly different only at 0.5 crown radius (Table 2). In the forest floor, mean arsenic levels increased and then declined with time after treatment, but there were no significant differences between pretreatment and 2-year post-treatment values at any distance. Levels in the forest floor declined linearly with distance. The arsenic concentration 
TABLE 1. Arsenic residues in environmental samples from a ponderosa pine foresta

\begin{tabular}{|c|c|c|c|c|c|c|}
\hline \multirow[b]{2}{*}{ Sample type } & \multicolumn{5}{|c|}{$\frac{\text { Concentration of arsenic }}{\text { Sampling time }}$} & \multirow[b]{2}{*}{$6 / 30 / 72$} \\
\hline & $\begin{array}{l}\text { Distance from } \\
\text { treated stem }\end{array}$ & $\begin{array}{c}7 / 9 / 70 \\
\text { (Pretreatment) }\end{array}$ & $9 / 4 / 70$ & \multicolumn{2}{|c|}{$6 / 15 / 71$} & \\
\hline & $\begin{array}{l}\text { Multiples of } \\
\text { crown radius }\end{array}$ & \multicolumn{5}{|c|}{ - } \\
\hline Hęrbage & $\begin{array}{l}0.5 \\
2 \\
4\end{array}$ & $\begin{array}{l}0.26 \pm 0.11 \\
0.14 \pm 0.05 \\
0.18 \pm 0.08\end{array}$ & $\begin{array}{l}1.34 \pm 1.67 \\
0.20 \pm 0.07 \\
0.18 \pm 0.08\end{array}$ & $\begin{array}{l}0.74 \pm \\
0.36 \pm \\
0.28 \pm\end{array}$ & $\begin{array}{l}0.27 \\
0.11 \\
0.08\end{array}$ & $\begin{array}{l}0.60 \pm 0.10 \\
0.52 \pm 0.34 \\
0.22 \pm 0.11\end{array}$ \\
\hline Browse & $\begin{array}{l}0.5 \\
2 \\
4\end{array}$ & $\begin{array}{l}0.24 \pm 0.05 \\
0.30 \pm 0.16 \\
0.28 \pm 0.08\end{array}$ & $\begin{array}{l}1.80 \pm 2.77 \\
0.30 \pm 0.07 \\
0.28 \pm 0.08\end{array}$ & $\begin{array}{l}0.44 \pm \\
0.34 \pm \\
0.40 \pm\end{array}$ & $\begin{array}{l}0.09 \\
0.11 \\
0.16\end{array}$ & $\begin{array}{l}0.68 \pm 0.64 \\
0.58 \pm 0.65 \\
0.42 \pm 0.43\end{array}$ \\
\hline Forest floor & $\begin{array}{l}0.5 \\
2 \\
4\end{array}$ & $\begin{array}{l}0.50 \pm 0.29 \\
0.92 \pm 0.43 \\
0.54 \pm 0.34\end{array}$ & $\begin{array}{l}1.18 \pm 0.70^{c} \\
0.54 \pm 0.23 \\
0.65 \pm 0.06\end{array}$ & $\begin{array}{l}43.2 \pm 2 \\
2.76 \pm \\
0.72 \pm\end{array}$ & $\begin{array}{l}21.5^{\mathrm{C}} \\
0.71^{\mathrm{C}} \\
0.62\end{array}$ & $\begin{array}{l}9.00 \pm 5.00 c \\
0.70 \pm 0.25 \\
0.64 \pm 0.36\end{array}$ \\
\hline Soild & $\begin{array}{l}0.5 \\
2 \\
4\end{array}$ & $\begin{array}{l}1.70 \pm 0.70 \\
1.90 \pm 0.65 \\
1.56 \pm 0.68\end{array}$ & $\begin{array}{l}1.60 \pm 0.34 \\
1.56 \pm 0.37 \\
1.58 \pm 0.19\end{array}$ & $\begin{array}{l}2.00 \pm \\
2.30 \pm \\
2.22 \pm\end{array}$ & $\begin{array}{l}0.91 \\
0.32 \\
0.40\end{array}$ & $\begin{array}{l}2.34 \pm 0.75 \\
1.92 \pm 0.55 \\
1.96 \pm 0.65\end{array}$ \\
\hline
\end{tabular}

Wenatchee National Forest

bean of five plots + standard deviation

C Concentration of arsenic is significantly different ( $P$ 0.05) from pretreatment levels at given distance from treated stem.

do-30 cm 
TABLE 2. Arsenic residues in environmental samples from a Douglas-fir foresta

\begin{tabular}{|c|c|c|c|c|c|}
\hline \multirow[b]{2}{*}{ Sample type } & \multirow[b]{2}{*}{$\begin{array}{l}\text { Distance from } \\
\text { treated stem }\end{array}$} & \multicolumn{4}{|c|}{$\begin{array}{c}\text { Concentration of arsenic } \\
\text { Sampling time }\end{array}$} \\
\hline & & $\begin{array}{c}7 / 29 / 70 \\
\text { (Pretreatment) }\end{array}$ & $10 / 1 / 70$ & $8 / 4 / 71$ & $6 / 13 / 72$ \\
\hline & $\begin{array}{l}\text { Multiples of } \\
\text { crown radius }\end{array}$ & \multicolumn{4}{|c|}{ - } \\
\hline $\begin{array}{c}\text { Herbage } \\
\quad\end{array}$ & $\begin{array}{l}0.5 \\
2 \\
4\end{array}$ & $\begin{array}{l}0.18+0.05 \\
0.18 \mp 0.08 \\
0.20 \pm 0.07\end{array}$ & $\begin{array}{l}1.72 \pm 1.63 \\
0.26 \pm 0.11 \\
0.26 \pm 0.05\end{array}$ & $\begin{array}{l}0.64 \pm 0.33 c \\
0.30 \mp 0.20 \\
0.28 \mp 0.16\end{array}$ & $\begin{array}{l}0.50 \pm 0.14 c \\
0.40 \mp 0.16 \\
0.34 \pm 0.13\end{array}$ \\
\hline Browse & $\begin{array}{l}0.5 \\
2 \\
4\end{array}$ & $\begin{array}{l}0.26 \pm 0.05 \\
0.22 \mp 0.11 \\
0.42 \pm 0.50\end{array}$ & $\begin{array}{l}0.24 \pm 0.15 \\
0.26 \mp 0.11 \\
0.24 \pm 0.11\end{array}$ & $\begin{array}{l}0.34 \pm 0.13 \\
0.24 \mp 0.15 \\
0.36 \pm 0.15\end{array}$ & $\begin{array}{l}0.78 \pm 0.36 c \\
0.48 \mp 0.26 \\
0.66 \mp 0.46\end{array}$ \\
\hline Forest floor & $\begin{array}{l}0.5 \\
2 \\
4\end{array}$ & $\begin{array}{l}0.76 \pm 0.40 \\
0.64 \mp 0.39 \\
0.82 \mp 0.49\end{array}$ & $\begin{array}{l}3.08 \pm 3.29 \\
1.02 \mp 0.43 \\
1.02 \pm 0.31\end{array}$ & $\begin{array}{l}3.42 \pm 1.66 \\
1.30 \mp 0.32 \\
0.84 \pm 0.15\end{array}$ & $\begin{array}{l}1.52 \pm 0.57 \\
1.38 \mp 0.67 \\
0.60 \pm 0.47\end{array}$ \\
\hline Soild & $\begin{array}{l}0.5 \\
2 \\
4\end{array}$ & $\begin{array}{l}1.02+0.37 \\
0.94 \mp 0.46 \\
1.02 \pm 0.27\end{array}$ & $\begin{array}{l}1.22 \pm 0.22 \\
1.24 \mp 0.31 \\
1.24 \pm 0.30\end{array}$ & $\begin{array}{l}2.12+0.74 c \\
1.82 \mp 0.60 \\
1.62 \pm 0.64\end{array}$ & $\begin{array}{l}2.04+0.84 c \\
1.88 \div 1.19 \\
2.00 \pm 0.86\end{array}$ \\
\hline
\end{tabular}

Wenatchee National Forest

bMean of five plots + standard deviation

${ }^{C}$ Concentration of arsenic is significantly different ( $P$. 0.05 ) from pretreatment levels at given distance from treated stem.

$\mathrm{d}_{0}-30 \mathrm{~cm}$ 
in soil increased after treatment, but differences between pretreatment and post-treatment values were significant only at 0.5 crown radius.

\section{Western Larch Forest}

Arsenic levels in herbs and browse in the western larch forest increased after treatment according to the analysis of variance, but differences between individual pre- and post-treatment values were not significant (Table 3 ). Levels in browse or herbs were not influenced by distance from treated trees. Arsenic concentration in the forest floor increased the first fall after treatment and then declined. All post-treatment values were significantly greater than the pretreatment values at a given distance from the stem, however. The arsenic level in soil did not change significantly with time for distance. Elevated levels in the forest floor were not reflected in the soil, indicating arsenic residues in the forest floor were tightly bound.

\section{Effect of Time and Distance}

The mean effects of time after application (averaged over the three distances) and distance from treated stems (averaged over the three post-treatment sampling times) on arsenic levels at all three study sites are in Fig. 1. Al though in many cases the effect of distance was not statistically significant, it appears based on the means, that post-treatment arsenic concentrations
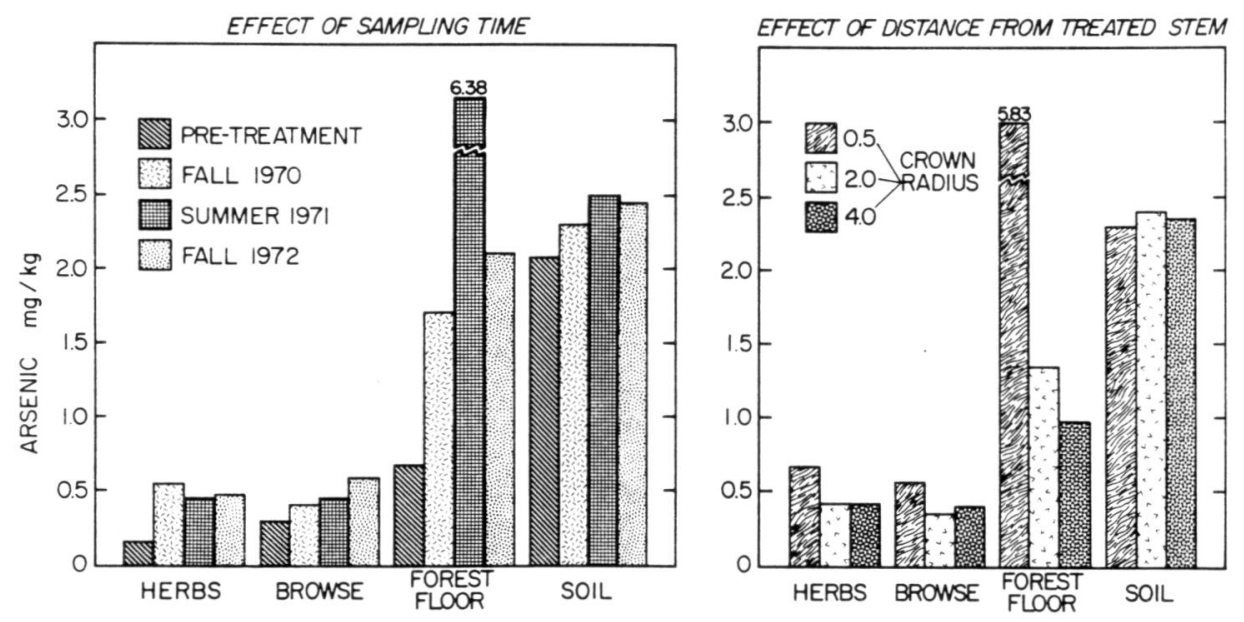

Fig. 1. The mean effect of time after application of MSMA (averaged over three distances) and distance from the treated stem (averaged over three post treatment sampling times; on the concentration of arsenic in herbs, browse, forest floor, and soil. 
TABLE 3. Arsenic residues in environmental samples from a western larch foresta

\begin{tabular}{|c|c|c|c|c|c|}
\hline \multirow[b]{2}{*}{ Sample type } & \multirow[b]{2}{*}{$\begin{array}{l}\text { Distance from } \\
\text { treated stem }\end{array}$} & \multicolumn{4}{|c|}{$\begin{array}{c}\text { Concentration of arsenic } \\
\text { SampTing time }\end{array}$} \\
\hline & & $\begin{array}{c}7 / 15 / 70 \\
\text { (Pretrea tment) }\end{array}$ & $9 / 5 / 70$ & $6 / 1 / 71$ & $5 / 15 / 72$ \\
\hline & $\begin{array}{l}\text { Multiples of } \\
\text { crown radius }\end{array}$ & \multicolumn{4}{|c|}{-mg/kgb } \\
\hline Herbage & $\begin{array}{l}0.5 \\
2 \\
4\end{array}$ & $\begin{array}{l}0.28+0.08 \\
0.26 \mp 0.25 \\
0.22 \pm 0.08\end{array}$ & $\begin{array}{l}0.32+0.11 \\
0.20 \mp 0.10 \\
0.26 \pm 0.15\end{array}$ & $\begin{array}{l}0.52+0.19 \\
0.40 \mp 0.20 \\
0.42 \pm 0.29\end{array}$ & $\begin{array}{l}0.66 \pm 0.51 \\
0.30 \mp 0.16 \\
0.68 \pm 0.41\end{array}$ \\
\hline Browse & $\begin{array}{l}0.5 \\
2 \\
4\end{array}$ & $\begin{array}{l}0.22 \pm 0.13 \\
0.36 \mp 0.26 \\
0.30 \pm 0.10\end{array}$ & $\begin{array}{l}0.30 \pm 0.23 \\
0.18 \mp 0.08 \\
0.16 \pm 0.09\end{array}$ & $\begin{array}{l}0.74+0.26 \mathrm{C} \\
0.48 \mp 0.31 \\
0.66 \pm 0.34\end{array}$ & $\begin{array}{l}0.46 \pm 0.35 \\
0.58 \mp 0.33 \\
0.52 \mp 0.45\end{array}$ \\
\hline Forest floor & $\begin{array}{l}0.5 \\
2 \\
4\end{array}$ & $\begin{array}{l}0.72+0.64 \\
0.56 \mp 0.33 \\
0.62 \mp 0.60\end{array}$ & $\begin{array}{l}2.92+1.35 c \\
2.68 \mp 0.83^{C} \\
2.36 \mp 0.21^{c}\end{array}$ & $\begin{array}{l}1.82+0.63 \mathrm{C} \\
1.78 \mp 0.84 \mathrm{C} \\
1.48 \pm 1.07 \mathrm{C}\end{array}$ & $\begin{array}{l}1.82+1.34 \mathrm{C} \\
1.86 \pm 0.48 \mathrm{C} \\
1.46 \pm 0.73 \mathrm{C}\end{array}$ \\
\hline Soild & $\begin{array}{l}0.5 \\
2 \\
4\end{array}$ & $\begin{array}{l}3.34+1.97 \\
3.20 \mp 1.61 \\
4.02 \mp 0.80\end{array}$ & $\begin{array}{l}3.54+1.35 \\
4.58 \mp 1.18 \\
4.20 \mp 1.09\end{array}$ & $\begin{array}{l}3.08+1.05 \\
3.84 \div 0.57 \\
3.62+0.49\end{array}$ & $\begin{array}{l}3.62+0.49 \\
3.34 \mp 0.28 \\
3.16+0.34\end{array}$ \\
\hline
\end{tabular}

\section{aColville National Forest}

bean of five plots \pm standard deviation

${ }^{C}$ Concentration of arsenic is significantly different ( $P$ ( 0.05 ) from pretreatment levels at given distance from treated stem.

d $0-30 \mathrm{~cm}$ 
were highest at 0.5 crown radius. The concentration appears to decrease with distance however. In most cases post-treatment concentrations at four times the crown radius were greater than the mean pretreatment concentration. The effect of time was somewhat variable, al though in nearly all cases, the concentration of arsenic was greater after treatment than before. The concentration most often reached a peak at the first or second post treatment sampling and then declined. In no case, was the mean concentration at the last sampling equal to or less than the pretreatment concentration, al though many of these apparent differences were not significant. These results suggest models can be used to construct "maps" of arsenic concentration in these forest types based on the number and location of treated trees and the time after application. This allows risk assessment to be tailored to the intensity of treatment.

\section{Arsenic in Stream Water}

Detectable levels of arsenic occurred in only four samples; in each case, the level was at the minimum detection limit of $0.01 \mathrm{mg} / \mathrm{L}$. Significant amounts of arsenic did not enter the water even though in two of the four areas, thinning was conducted on both sides of the stream. WAUCHOPE (1975) concluded the arsenical herbicides poses little threat to groundwater by leaching. Overland flow of water seldom occurs on forest land; so stream contamination by this route is unlikely.

\section{DISCUSSION}

Arsenic residues in browse and herbaceous vegetation were relatively low, al though it is clear some increase in arsenic level did occur after treatment of nearby trees. The increase was slightly greater than anticipated considering the minor changes in arsenic level in soil. DUBLE, et al. (1969) reported only $1.6 \mathrm{mg} / \mathrm{kg}$ arsenic in tops of Bermuda grass plants 7 days after treating the soil with $17.9 \mathrm{~kg} / \mathrm{ha}$ disodium methanearsonate. They indicated the arsenic was relatively unavailable for uptake. Tolerances of $0.6 \mathrm{mg} / \mathrm{kg}$ and $2.0 \mathrm{mg} / \mathrm{kg}$ arsenic have been established for MSMA and cacodylic acid in cottonseed hulls for cattle feed ${ }^{2}$. Most of the arsenic residues in vegetation in our study fall within these tolerances; however, our analytical procedure did not distinguish among arsenic species.

Maycumber reported (NORRIS 1971) cattle grazed in forest areas during and after operational thinning with MSMA showed no mortality despite 3 month's exposure to vegetation which presumably contained arsenic levels comparable to those reported in our study. No significant pathological lesions or arsenic residues were found in tissues from these animals. In a similiar study, NORRIS (1977) reported no significant increase in arsenic

2Federal Register: December 3, 1970 and January 18, 1972. 
levels in hair of cattle grazed for 5 months in areas

operationally thinned with MSMA.

In our study large quantities of arsenic did not move from the forest floor into the soil, indicating arsenic residues in the foliage of conifers are relatively tightly bound and not subject to significant leaching action. Decreasing arsenic concentrations in forest floor with no significant increase in the soil suggest the total load of arsenic decreased with time, possibly due to volatilization of arsine derivatives (CHALLENGER 1951, RAY 1975). In an agricultural soi1, ROBINSON (1975) reported no increase in elemental arsenic, even after five annual applications at rates up to $36 \mathrm{~kg} / \mathrm{ha}$. The concentration of arsenic we found in forest floor and soil will not have a marked effect on the metabolism of microorganisms. BOLLEN et al. (1974, 1977 ) reported $10 \mathrm{mg} / \mathrm{kg}$ arsenic as cacodylic acid or MSMA had no effect on microbial carbon or nitrogen metabolism in forest floor and soils from the three forests in our study.

\section{ACKNOWLEDGMENT}

We are grateful to those on the Kaniksu, Colville, and Wenatchee National Forests for their considerable help with this study and to J. Hazard and D. Henshaw of the Pacific Northwest Forest and Range Experiment Station for statistical assistance.

\section{REFERENCES}

ASSOCIATION OF OFFICIAL ANALYTICAL CHEMISTS: Official Methods of Analysis. Eleventh Edition, 399 (1970).

BOLLEN, W. B., L. A. NORRIS, and K. L. STOWERS: Weed Sci. 22, $557(1974)$.

BOLLEN, W. B., L. A. NORRIS, and K. L. STOWERS: I. Environ. Qual. 6, 1 (1977).

CHALLENGER, F.: Advances in Enzymology. 12, 429 (1951).

DUBLE, R. L., E. C. HOLT, G. G. MCBEE: J. Agric. Food Chem. $17,1247^{\prime}(1969)$.

FRANKLIN, J. F. and C. T. DYRNESS: USDA For. Serv. Gen. Tech. Rep. PNW-8, Pac. Northwest For. and Range Exp. Stn., Portland, Oreg. 417 p. (1973).

NORRIS, L. A.: Precommercial thinning of coastal and intermountain forests in the Pacific Northwest. p. 63, Wash. State Univ., Pullman. (1971).

NORRIS, L. A.: USDA For. Serv. Res. Note, PNW-296. Pac. Northwest For. and Range Exp. Stn., Portland, Oreg. 9 p. (1977).

RAY, B.: Int. Pest. Contr. 17, 9 (1975).

ROBINSON, E. L.: Weed Sci. 23, 341 (1975).

WAUCHOPE, R. D: J. Environ. Qual. 4, 355 (1975).

Accepted December 26, 1982

Purchased by USDA Forest Service for Official Use 